\title{
Case Report Myxedema Coma Complicated by Pancytopenia
}

\author{
Charles T. Mupamombe $\mathbb{D}^{1},{ }^{1}$ Felix M. Reyes $\mathbb{D}^{1},{ }^{1}$ Derek B. Laskar, ${ }^{2}$ and Joseph Gorga ${ }^{3}$ \\ ${ }^{1}$ SUNY Downstate Medical Center, Department of Medicine, Brooklyn, NY, USA \\ ${ }^{2}$ SUNY Downstate Medical Center, Department of Pathology, Brooklyn, NY, USA \\ ${ }^{3}$ Kings County Hospital Center, Department of Pulmonary and Critical Care, Brooklyn, NY, USA
}

Correspondence should be addressed to Charles T. Mupamombe; ctmupamom@gmail.com

Received 4 March 2019; Accepted 1 July 2019; Published 14 July 2019

Academic Editor: Dante Amato

Copyright (C) 2019 Charles T. Mupamombe et al. This is an open access article distributed under the Creative Commons Attribution License, which permits unrestricted use, distribution, and reproduction in any medium, provided the original work is properly cited.

Hypothyroidism is common, with an extreme manifestation of myxedema coma if untreated. Hematologic consequences of myxedema coma include mild leukopenia and anemia, rarely pancytopenia. We present a patient with typical symptoms of myxedema coma, but found to be pancytopenic, with sustained response to levothyroxine and blood transfusion for anemia.

\section{Background}

The American Thyroid Association estimates more than $12 \%$ of the US population will develop a thyroid condition and 20 million people have some form of thyroid disease. More than half of these people will be undiagnosed [1]. Hypothyroidism is the most common thyroid disorder. Symptoms usually include tiredness, mental depression, sluggishness, cold intolerance, weight gain, dry skin and hair, constipation, and menstrual irregularities in women [2]. The most extreme manifestation of untreated hypothyroidism is myxedema coma, which carries a mortality rate as high as $25-60 \%$ [3]. A few cases in the literature have been reported of hematologic manifestations due to hypothyroidism, which resolved following adequate thyroid hormone replacement [4-7]. We present a case of a patient whose initial known thyroid disorder presentation was myxedema coma, with a complication of pancytopenia.

\section{Case}

A 71-year-old female who had a reported history of dementia and depression, being treated with carbidopa-levodopa, memantine, quetiapine, selegiline, and sertraline, was brought in by her family for refusal to eat, walk, or talk. The family of the patient endorsed that the patient had gone from hospital to hospital and always been diagnosed with dementia.
Her prescriptions were always obtained from emergency departments. A primary care physician was not provided, and it was not clear who had initially prescribed these medications.

Her vital signs were significant for hypothermia, with a temperature of $91^{\circ} \mathrm{F}\left(32.8^{\circ} \mathrm{C}\right)$; she had bradycardia at 33 beats per minute; oxygen saturation by pulse oximetry was $90 \%$ on room air; and her initial blood pressure was $128 / 72 \mathrm{mmHg}$. On physical examination, she was contracted and cachectic but withdrawing to pain, she had a regular rhythm and rate of the heart, and her extremities were nonedematous. There was evidence of hair loss on her head. The rest of her physical examination was unremarkable.

While in the emergency department, her systolic blood pressure decreased to $60 \mathrm{mmHg}$, unresponsive to aggressive resuscitation with intravenous fluids. The Emergency Room physicians treated her with vasopressors to maintain an adequate mean arterial pressure for perfusion. In addition, her mental state deteriorated further, becoming increasingly altered and eventually falling into a soporous state. She was intubated for airway protection. She was transferred to the Medical Intensive Care Unit for further care and evaluation. Her home medications were not continued at this point.

Her initial complete blood count (CBC) was significant for white blood cell count (WBC) of $1.4 / \mathrm{nL}$ (absolute neutrophil count $(\mathrm{ANC})$ of $\left.1086 \times 10^{3} / \mu \mathrm{L}\right)$, hemoglobin $(\mathrm{Hb})$ of $12.3 \mathrm{~g} / \mathrm{dL}$, hematocrit of $33 \%$, platelet count of $104 / \mathrm{nL}$, and 
MCV of $79.5 \mathrm{fL}$ (78-95). Her reticulocytes were $0.51 \%$, with a reticulocyte index of 0.30 (using the lower limit normal hematocrit for our lab of 37\%). During the first week of admission, her WBC reached a nadir of $0.76 / \mathrm{nL}$ (ANC $496 \times 10^{3} / \mu \mathrm{L}$ ) and $\mathrm{Hb}$ nadir of $6.6 \mathrm{~g} / \mathrm{dL}$, without any evidence of hemorrhage identified. Her platelets reached a nadir of 48/ $\mathrm{nL}$. Her creatinine level was $0.34 \mathrm{mg} / \mathrm{dL}$, with a blood urea nitrogen level of $25 \mathrm{mg} / \mathrm{dL}$. Our theory at the time was hemoconcentration, with administration of fluid subsequently causing a dilution effect. This was suggested by her serum total protein decrease from $6.1 \mathrm{~g} / \mathrm{dL}(6-8.5)$ on arrival to $4.3 \mathrm{~g} / \mathrm{dL}$ after continuous fluid resuscitation. Her creatine kinase (CK) level was elevated, measuring 687 U/L (20-180).

Her thyroid-stimulating hormone was $24.5 \mathrm{miU} / \mathrm{L}$ (0.27-4.20); free thyroxine was measured at $0.886 \mathrm{ng} / \mathrm{dL}$ (0.93-1.70); total thyroxine (T4) was $3.7 \mu \mathrm{g} / \mathrm{dL}$ (4.5-11.7); free triiodothyronine (T3) was $0.989 \mathrm{pg} / \mathrm{mL}$; and total T3 was $36.31 \mathrm{ng} / \mathrm{dL}$ (80-200). Her PM random cortisol level was $16.2 \mu \mathrm{g} / \mathrm{dL}$ (AM range 6.2-19.54; PM range 2.3-11.9). Her thyroid-stimulating immunoglobulin was 55\% (0-139\%), and T3 uptake was $37.45 \%(28-41 \%)$.

She had a serum sodium level of $114 \mathrm{mmol} / \mathrm{L}$ (136-146) and serum potassium level of $4.6 \mathrm{mmol} / \mathrm{L}$ (3.5-5.0). Her serum osmolality was $245 \mathrm{mOsm} / \mathrm{L}$ (275-295), urine sodium $68 \mathrm{mmol} / \mathrm{L}$, and urine osmolality $401 \mathrm{mOsm} / \mathrm{L}$ (300-1000). Her AST level was elevated to 96 U/L (10-35) and ALT 72 U/ L (0-31). Her urinalysis was not suggestive of an infectious process. Her venous lactate reached a high level of $2.7 \mathrm{mmol} /$ L (0.5-2.2), but decreased to normal with hydration and remained as such throughout her stay in the MICU. Urine toxicology was negative. Blood culture and urine culture were unremarkable for any organisms. See Table 1 for a summary of selected results.

A chest X-ray obtained was unremarkable. Computed tomography (CT) of the head without contrast revealed a prominent bilateral, symmetric occipital-parietal white matter hypodensity with preserved overlying gray matter attenuation without significant local mass effect. The reviewing radiologist suggested this could be related to posterior reversible encephalopathy syndrome, sequela of hypoglycemia, or progressive multifocal leukoencephalopathy (PML) in the proper clinical setting. A magnetic resonance image (MRI) of the brain without contrast was obtained due to a continued nonresponsive state and to further investigate the results of the CT of the head. This revealed multifocal areas of recent ischemic infarction involving large areas of the bilateral posterior cerebral artery (PCA) territories, the left middle cerebral artery (MCA) territory, and small infarcts in the right anterior cerebral artery (ACA) and bilateral watershed areas (Figures 1 and 2).

The probability of myelodysplastic syndromes (MDSs) was high, so we sought a bone marrow biopsy for further investigation. However, her family opted not to have this procedure performed. We decided to obtain a peripheral blood smear and flow cytometry; in the meantime, this gave the family more time to decide on goals of care. The peripheral blood smear revealed decreased white blood cells, few neutrophils which were hypolobulated and hypergranular; normocytic normochromic red blood cells, rare polychromasia without tear drop cells; and decreased platelets, without clumping (Figure 3). Serum electrophoresis for gamma globulins was within normal ranges. Flow cytometry returned as normal. Serum vitamin B12 and folate were within acceptable range.

She was treated with normal saline and empiric broadspectrum antibiotics. Thyroid myxedema was the most likely differential, so she was started on hydrocortisone and intravenous levothyroxine. Her WBC count improved to $5.43 / \mathrm{nL}$ 9 days after initiation of levothyroxine. Her platelets also improved to a count within a normal laboratory range of 148/ $\mathrm{nL} 13$ days after initiation of levothyroxine. For unclear reasons, she had a sudden decline in hemoglobin on day 18 to a level of $5.7 \mathrm{~g} / \mathrm{dL}$, which was confirmed on repeat CBC. She received 2 units of packed red blood cells (PRBCs) as treatment. There was no evidence of hemolysis on her lab values or signs of any hemorrhage. Her $\mathrm{Hb}$ improved to $10.2 \mathrm{~g} / \mathrm{dL}$ after transfusion and remained between 9 and $10 \mathrm{~g} / \mathrm{dL}$ for the remainder of her admission, without further need for transfusion throughout her stay. Unfortunately, our patient did not return to a conscious state and expired after 32 days as an inpatient.

\section{Discussion}

Our differential diagnosis for the cause of the hematologic disturbances in our patient included hypothyroidism, sepsis, drug-induced hemorrhage, and nutritional deficiencies. We will discuss in brief some of them below based on a brief literature review.

The pathogenesis of anemia in hypothyroidism may be related to decreased oxygen requirement due to a decrease in the basal metabolic rate [6]. Pancytopenia due to marrow hypoplasia has been hypothesized and reported in patients with myxedema coma but does not seem to be commonplace $[6,8]$. If it occurs in uncomplicated hypothyroidism, anemia is characteristically normochromic and normocytic, less common is macrocytic or microcytic [6]. Some sources report the incidence of anemia in uncomplicated hypothyroidism to be slightly less than 30\% [6]. Patients with hypothyroidism are known to have reduced levels of erythropoietin, with one theory being due to reduced renal perfusion [9]. Table 2 summarizes some cases found in the literature linking pancytopenia to hypothyroidism. Interestingly, all cases found were of female patients.

Hemorrhagic shock has been shown to suppress early and late progenitor cell growth in rats [12]. We are unsure if the same link exists in humans. Splanchnic hypoperfusion may play a role in bone marrow ischemia as proposed by some investigators [13]. Other signs of systemic hypoperfusion would be expected to be seen, such as ischemic hepatitis, due to profound hypotension [14]. The serum lactate level would also be predicted to be significantly elevated in such patients [15].

Medications should always be on the differential for potential causes of bone marrow injury. Memantine is $45 \%$ protein bound, undergoes partial hepatic metabolism, and has $74 \%$ renal excretion of its 3 minimally active metab-

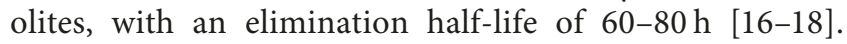
Quetiapine is $83 \%$ protein bound, primary hepatically 
TABLE 1: Summary of selected results.

\begin{tabular}{|c|c|c|c|c|}
\hline Day 1 (range) & Day 3 & Day 9 & Day 13 & Day 20 \\
\hline WBC $1.4 / \mathrm{nL}(4.5-10.9)$ & WBC $0.76 / \mathrm{nL}$ & WBC $5.43 / \mathrm{nL}$ & WBC $5.64 / \mathrm{nL}$ & WBC $8.49 / \mathrm{nL}$ \\
\hline $\mathrm{Hb} 12.3 \mathrm{~g} / \mathrm{dL}(12-16)$ & $\mathrm{Hb} 9.2 \mathrm{~g} / \mathrm{dL}$ & $\mathrm{Hb} 8.1 \mathrm{~g} / \mathrm{dL}$ & $\mathrm{Hb} 7.1 \mathrm{~g} / \mathrm{dL}$ & $\mathrm{Hb} 9.1 \mathrm{~g} / \mathrm{dL}$ \\
\hline Hct $33 \%(37-47)$ & Hct $27.1 \%$ & Hct $22.6 \%$ & Hct $21.8 \%$ & Hct $27.2 \%$ \\
\hline Plt 104/nL (130-400) & Plt 46/nL & Plt 85/nL & Plt $148 / \mathrm{nL}$ & Plt 388/nL \\
\hline $\mathrm{Na} 114 \mathrm{mmol} / \mathrm{L}(136-146)$ & & $\mathrm{Na} 141 \mathrm{mmol} / \mathrm{L}$ & & \\
\hline $\mathrm{K} 4.6 \mathrm{mmol} / \mathrm{L}(3.5-5.0)$ & & $\mathrm{K} 3.4 \mathrm{mmol} / \mathrm{L}$ & & \\
\hline $\mathrm{Cl} 78 \mathrm{mmol} / \mathrm{L}(98-106)$ & & $\mathrm{Cl} 100 \mathrm{mmol} / \mathrm{L}$ & & \\
\hline BUN 25 mg/dL (8-23) & & BUN $22 \mathrm{mg} / \mathrm{dL}$ & & \\
\hline Cr $0.34 \mathrm{mg} / \mathrm{dL}(0.50-0.90)$ & & Cr $0.43 \mathrm{mg} / \mathrm{dL}$ & & \\
\hline TSH $24.5 \mathrm{miU} / \mathrm{L}(0.27-4.20)$ & & & TSH $4.82 \mathrm{miU} / \mathrm{L}$ & \\
\hline Free T4 $0.886 \mathrm{ng} / \mathrm{dL}(0.93-1.70)$ & & & Free T4 $0.478 \mathrm{ng} / \mathrm{dL}$ & \\
\hline Total T4 $3.7 \mu \mathrm{g} / \mathrm{dL}(4.5-11.7)$ & & & Total T4 2.34 & \\
\hline Free T3 $0.989 \mathrm{pg} / \mathrm{mL}$ & & & & \\
\hline Total T3 $36.31 \mathrm{ng} / \mathrm{dL}(80-200)$ & & & & \\
\hline
\end{tabular}

WBC, white blood cells; Hb, hemoglobin; Hct, hematocrit; Plt, platelet; Na, sodium; K, potassium; Cl, chloride; BUN, blood urea nitrogen; Cr, creatinine; $\mathrm{TSH}$, thyroid-stimulating hormone; T4, thyroxine; T3, triiodothyronine.

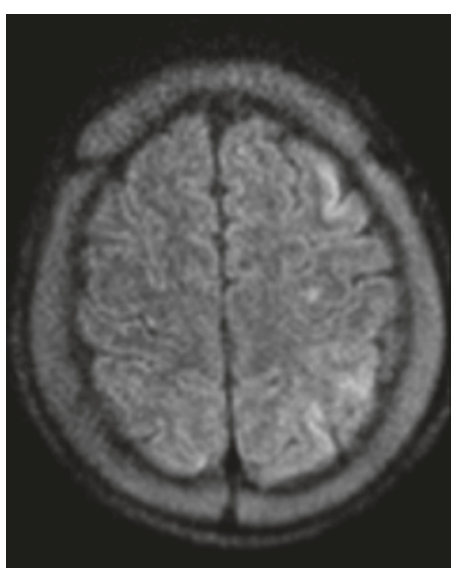

(a)

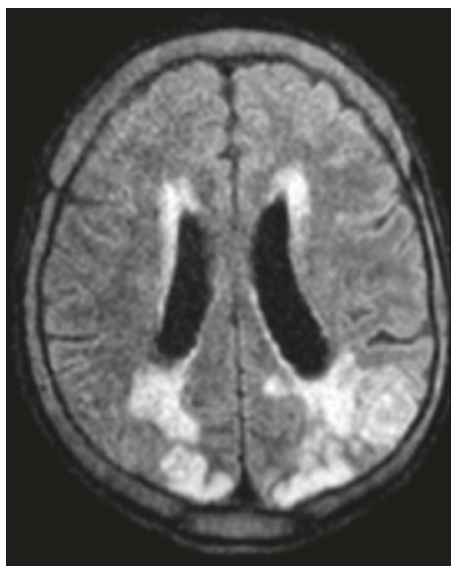

(d)

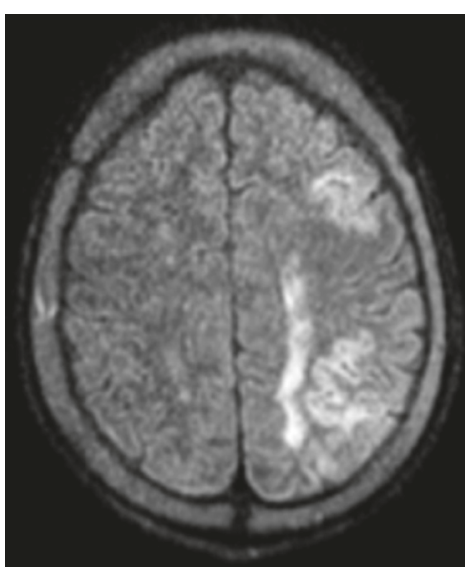

(b)

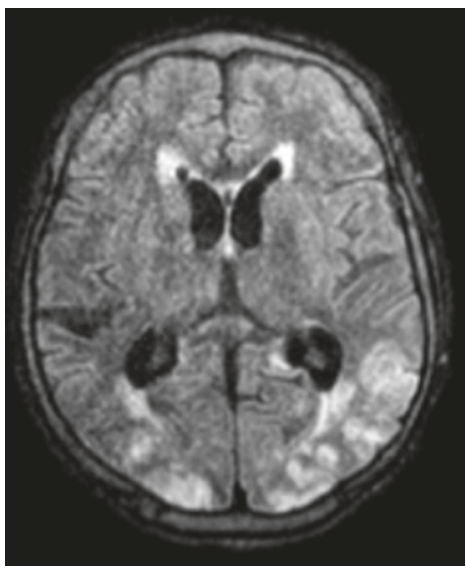

(e)

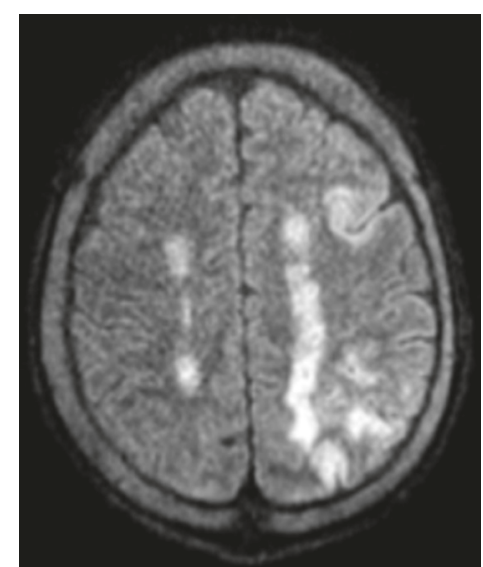

(c)

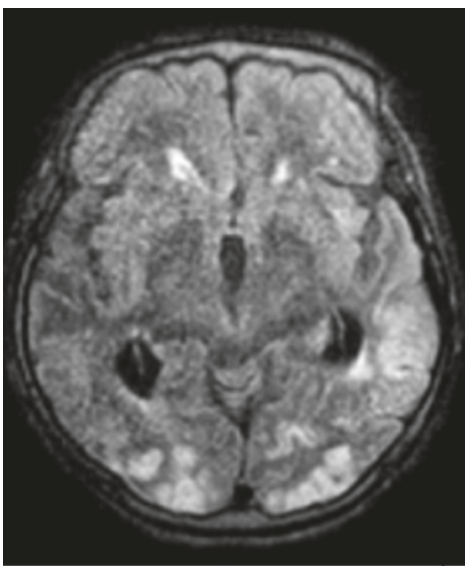

(f)

FIGURE 1: T2-weighted MRI without contrast images of the brain. The hyperintense areas reflect areas of ischemia. These were reviewed as recent infarcts in the ACA, MCA, and PCA territories. No intracranial hemorrhage can be identified. The radiologist also noted a mild mass effect with no midline shift.

metabolized, and has $73 \%$ renal excretion, with a half-life of approximately 6-7 h [16-18]. Both memantine and quetiapine are metabolized via the cytochrome P450 family of enzymes. Memantine may be associated with agranulocytosis, leukopenia, pancytopenia, and thrombocytopenia according to postmarketing surveillance in a report by the United States Food and Drug Administration (FDA) [17, 19]. Quetiapine is also associated with neutropenia in postmarketing 


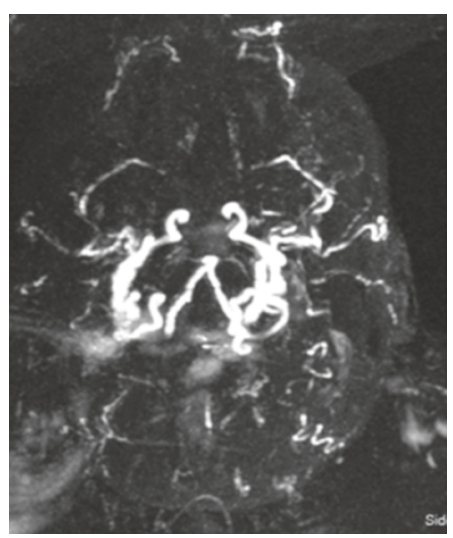

(a)

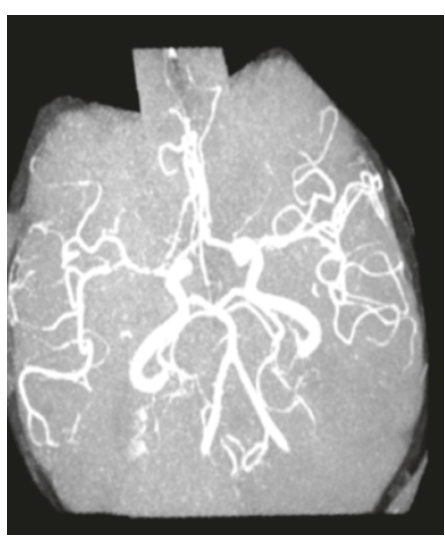

(b)

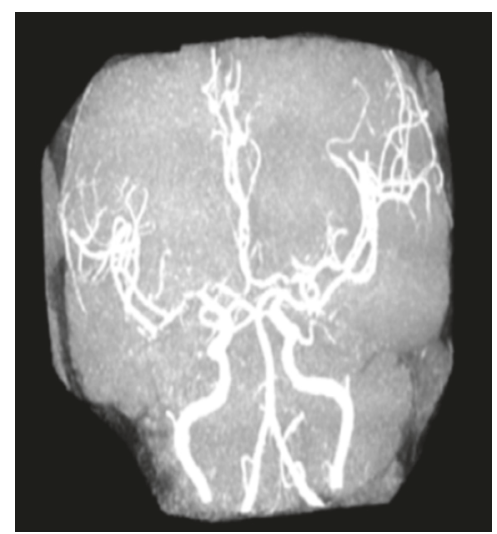

(c)

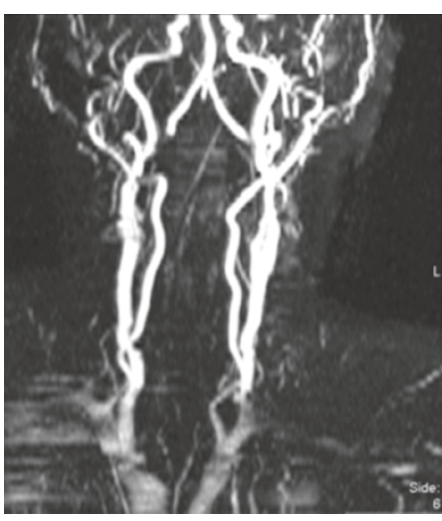

(d)

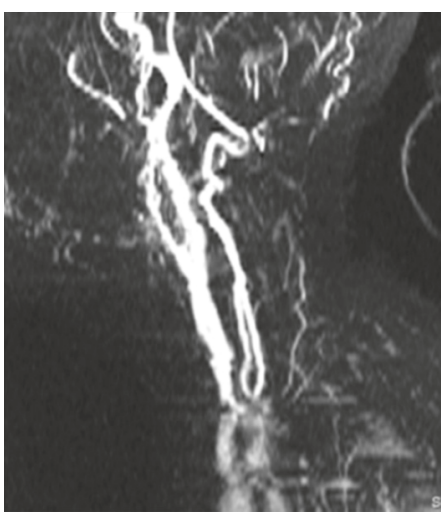

(e)

FIgURE 2: Magnetic resonance angiography (MRA) images of the head and neck are shown. The top 3 panels show MRA of the head, reviewed as multifocal areas of irregularity and narrowing within the anterior and posterior circulations, including pronounced stenosis of the bilateral carotid termini, middle cerebral arteries, right ACA A1 segment, and right PCA P3 and P4 segments with nonvisualization of the mid to distal right and P4 segment. The bottom panels show MRA of the neck, which was reviewed as unremarkable.

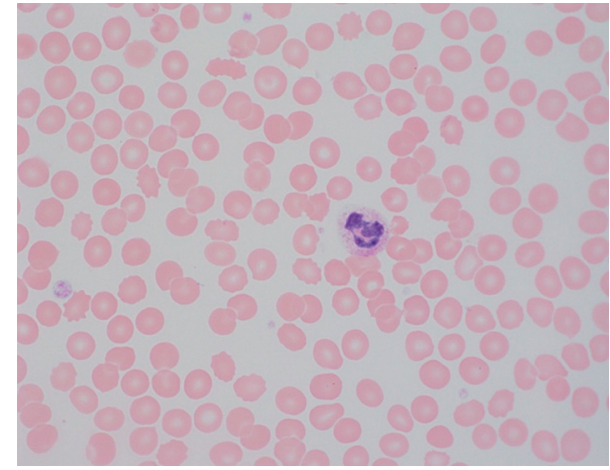

Figure 3: Peripheral blood smear shows pancytopenia with paucity of leukocytes, erythrocytes, and platelets. A neutrophil with cytoplasmic toxic granulations and adjacent platelet is seen (Wright-Giemsa, original magnification $\times 100$ ).

surveillance data [19]. According to the FDA, data disclosing the effects of both quetiapine and memantine on white blood cells are lacking, and the frequency of these effects could not be determined.

Medication-induced pancytopenia could have played a role for our patient; however, the relatively short period of time that her cell counts improved upon discontinuation of possible offenders made this unlikely. The long half-life of memantine could mean continued pharmacologic effect even with acute cessation; however, we would theorize a longer time for cell counts to improve than what we observed. However, the same argument cannot be applied for quetiapine due to a shorter half-life. In addition, the lack of a defined frequency via postmarketing data suggests that these side effects for both medications are extremely rare, and more studies are needed to confirm the link. We would also expect a cocktail of the more common side effects to have been observed at presentation, reversing upon cessation of medications, but this was not the case.

Cytopenias due to nutritional deficiencies, including folate and vitamin B12, have been well described in the literature, with marked improvement upon administration $[11,20-22]$. In the case of folate and vitamin B12, there is an arrest in development in all cell lines, leading to decreased cell counts [20]. This is of particular concern in the elderly who are at increased risk of malnutrition. McHamon and Kamath reported a case of pancytopenia associated with vitamin B12 deficiency secondary to pernicious anemia, which improved upon vitamin B12 supplementation [11]. This etiology is reversible upon administration of the deficient nutrient; therefore, it is important for clinicians to 
TABLE 2: Some reported cases of pancytopenia associated with hypothyroidism found in the literature $[4-6,8,10,11]$.

\begin{tabular}{|c|c|c|c|c|c|c|}
\hline Author(s) & Age & Sex & Presentation & Cell count & Treatment & Outcome \\
\hline $\begin{array}{l}\text { McMahon and } \\
\text { Kamath [11] }\end{array}$ & 25 & $\mathrm{~F}$ & $\begin{array}{l}\text { Known hypothyroidism, } \\
\text { iron deficiency anemia, } \\
\text { fatigue, weight loss }\end{array}$ & $\begin{array}{l}\text { WBC } 3800 / \mu \mathrm{L} \\
\text { Hemoglobin } \\
6.9 \mathrm{~g} / \mathrm{dL} \\
\text { Platelet } \\
158 \times 10^{9} / \mathrm{L}\end{array}$ & $\begin{array}{l}\text { Levothyroxine + vitamin } \\
\text { B12 }\end{array}$ & $\begin{array}{l}\text { Complete resolution of } \\
\text { pancytopenia on } 2 \text {-month } \\
\text { follow-up }\end{array}$ \\
\hline $\begin{array}{l}\text { Rathi and Peacey } \\
{[6]}\end{array}$ & 64 & $\mathrm{~F}$ & $\begin{array}{l}\text { No past medical history, } 4- \\
\text { week history of bilateral leg } \\
\text { swelling, tiredness, dry skin }\end{array}$ & $\begin{array}{l}\text { WBC } 2900 / \mu \mathrm{L} \\
\text { Hemoglobin } \\
10.2 \mathrm{~g} / \mathrm{dL} \\
\text { Platelet } \\
127 \times 10^{9} / \mathrm{L} \\
(150-400)\end{array}$ & Levothyroxine & $\begin{array}{l}\text { Complete resolution of } \\
\text { proteinuria and } \\
\text { pancytopenia on 3-month } \\
\text { follow-up after discharge }\end{array}$ \\
\hline Tsoukas [4] & 82 & $\mathrm{~F}$ & $\begin{array}{l}\text { Confusion, lethargy, } \\
\text { bradycardia, hypothermia, } \\
\text { respiratory stridor, no past } \\
\text { medical history }\end{array}$ & $\begin{array}{l}\text { WBC } 3990 / \mu \mathrm{L} \\
\text { Hemoglobin } \\
8.5 \mathrm{~g} / \mathrm{dL} \\
\text { Platelet } \\
27 \times 10^{9} / \mathrm{L}\end{array}$ & $\begin{array}{c}\text { IV hydrocortisone + IV } \\
\text { levothyroxine, subsequent } \\
\text { PO levothyroxine on } \\
\text { discharge }\end{array}$ & $\begin{array}{l}\text { Complete resolution of } \\
\text { pancytopenia on } 4 \text {-week } \\
\text { follow-up after discharge }\end{array}$ \\
\hline Song et al. [8] & 68 & $\mathrm{~F}$ & $\begin{array}{l}\text { Increasing immobility over } \\
12 \text { months, alopecia, drowsy, } \\
\text { slurred speech, deep voice, } \\
\text { no other past medical history }\end{array}$ & $\begin{array}{l}\text { WBC } 1600 / \mu \mathrm{L} \\
\text { Hemoglobin } \\
8.2 \mathrm{~g} / \mathrm{dL} \\
\text { Platelet } \\
35 \times 10^{9} / \mathrm{L}\end{array}$ & $\begin{array}{c}\text { IV hydrocortisone + IV } \\
\text { triiodothyronine, oral } \\
\text { levothyroxine replacement } \\
1 \text { week later }\end{array}$ & $\begin{array}{l}\text { Resolution of white cell } \\
\text { count and platelet count at } \\
6 \text { weeks on discharge } \\
\text { Improved hemoglobin at 4- } \\
\text { month follow-up after } \\
\text { discharge }\end{array}$ \\
\hline $\begin{array}{l}\text { Lee AC [5], letter } \\
\text { to the editor }\end{array}$ & 11 & $\mathrm{~F}$ & $\begin{array}{l}\text { Patient developed } \\
\text { postablative hypothyroidism } \\
\text { and pancytopenia after } \\
\text { radiotherapy for suprasellar } \\
\text { germinoma }\end{array}$ & $\begin{array}{c}\text { Absolute } \\
\text { neutrophil } 0 \\
\text { Hemoglobin } \\
6.9 \mathrm{~g} / \mathrm{dL} \\
\text { Platelet } \\
8 \times 10^{9} / \mathrm{L}\end{array}$ & $\begin{array}{l}\text { Packed red blood cell and } \\
\text { platelet transfusions, } \\
\text { thyroxine } \\
\text { replacement }+ \text { hormonal } \\
\text { replacement }\end{array}$ & $\begin{array}{l}\text { Pancytopenia resolved } \\
\text { within a week of thyroid } \\
\text { hormone replacement }\end{array}$ \\
\hline $\begin{array}{l}\text { Shaaban et al. } \\
{[10]}\end{array}$ & 57 & $\mathrm{~F}$ & $\begin{array}{l}\text { Restlessness, increased } \\
\text { fatigue, weight gain, puffy } \\
\text { face }\end{array}$ & $\begin{array}{l}\text { WBC } 2500 / \mu \mathrm{L} \\
\text { Hemoglobin } \\
8.4 \mathrm{~g} / \mathrm{dL} \\
\text { Platelet } \\
95 \times 10^{9} / \mathrm{L} \\
\end{array}$ & $\begin{array}{c}\text { Initially IV and PO } \\
\text { levothyroxine, discharged on } \\
\text { PO only }\end{array}$ & $\begin{array}{l}\text { White cell count improved } \\
\text { after } 1 \text { week of thyroid } \\
\text { replacement, at } 3 \text {-month } \\
\text { follow-up, her hematologic } \\
\text { counts were stable }\end{array}$ \\
\hline
\end{tabular}

check the levels of folate and vitamin B12 whenever a deficiency is suspected.

Our patient presented with multiple signs associated with myxedema coma: alopecia, bradycardia, altered mental state, hypotension, hyponatremia, elevated CK, initial mild leukopenia, and initial mild anemia [23]. In hindsight, the precipitating event could have been the stroke found on subsequent MRI of the brain, as this has been reported to induce myxedema coma [23]. She may have been among the 20 million estimated not to be aware of their thyroid condition, which was brought to light on this admission in its extreme manifestation. With our patient in the geriatric range, her hypothyroid probably presented in an atypical fashion [23], with decreased mobility and poor cognition, inappropriately diagnosed as dementia.

Our patient presented with hypotension, requiring vasopressor support to maintain perfusion. However, she did not exhibit a markedly impressive sign of hypoperfusion via serum lactate, which made bone marrow failure secondary to shock (hypoperfusion) lower on our differential. This lack of lactate production may be explained by decreased tissue metabolic demand secondary to decreased thyroid hormone. Her reticulocyte index was low, suggesting inadequate bone marrow response to anemia. Here, we would hypothesize this to be secondary to a lack of thyroid hormone.
Hypothermia, decreased WBCs, and hypotension can be seen in septic patients. In addition, the hypergranulations found in the neutrophils could be seen in an infection in some cases, but can be nonspecific. What argued against an infective process in our patient are the negative blood and urine cultures.

She had a significant decrease in the hemoglobin level, requiring transfusion of red blood cells. This fact is a confounder in whether her red blood cells would have improved on thyroid supplementation alone or not; however, it was deemed necessary to transfuse her at the time to try to improve her clinical status. What favors the argument that thyroid hormone played a significant role is that she did not require further transfusions throughout her admission as blood transfusion was administered relatively early in her clinical course. We suspect it may have been too early to have seen the effects of the thyroid hormone replacement. Her response to the blood transfusion was also very robust and unexpected, increasing from $6.6 \mathrm{~g} / \mathrm{dL}$ to $10.2 \mathrm{~g} / \mathrm{dL}$ after only just 2 units of packed red blood cells. It is not clear why this was observed; perhaps, the transfusion improved perfusion to her kidneys and, in turn, improved her erythropoietin production, sustaining her hemoglobin level from then on. She remained anemic but stable, which is an expected parameter in hypothyroidism. 
A bone marrow biopsy would have helped in the diagnosis of her hematologic pathology; however, it was not ethically justified; the family wishes had to be respected. Moreover, a normal flow cytometry with normalizing white cell count on repeat testing left little support for its pursuit, especially given her continued soporous state. Although mild leukopenia and mild anemia can be present in patients with myxedema [23], having them occur simultaneously to the levels seen in our patient, along with added thrombocytopenia, makes our case unusual. This could support the theory of bone marrow hypoplasia in severe hypothyroidism.

With all the data that were collected and available to us, we believe the patient had pancytopenia secondary to hypothyroidism which presented as myxedema. This is supported by her cell counts normalized soon after administration of intravenous levothyroxine. Our case highlights the importance of maintaining hypothyroidism on the differential for reversible causes of anemia and dementia from a primary care perspective, as it appears she had moved from provider to provider without this being addressed. From a critical care point, pancytopenia should be managed as a part of a multisystemic complication of myxedema coma, knowledge of which can help guide management for critical care providers.

\section{Additional Points}

Hypothyroidism is common and should be considered as part of the differential diagnosis in patients with abnormal hematologic parameters. Pancytopenia can be part of a multisystemic complication of severe hypothyroidism.

\section{Conflicts of Interest}

The authors have no conflicts of interest to disclose.

\section{References}

[1] 2019, https://www.thyroid.org.

[2] D. Cooper, M. McDermott, and L. Wartofsky, "Hypothyroidism," Journal of Clinical Endocrinology \& Metabolism, vol. 89, no. 11, 2004.

[3] V. Matthew, R. A. Misgar, S. Ghosh et al., "Myxedema coma: a new look into an old crisis," Journal of Thyroid Research, vol. 2011, Article ID 493462, 7 pages, 2011.

[4] M. A. Tsoukas, "Pancytopenia in severe hypothyroidism," American Journal of Medicine, vol. 127, no. 9, pp. e11-e12, 2014.

[5] A. C.-W. Lee, "Pancytopenia secondary to hypopituitarism may just be due to hypothyroidism alone," Annals of $\mathrm{He}$ matology, vol. 89, no. 11, p. 1181, 2010.

[6] M. S. Rathi and S. R. Peacey, "Pancytopenia and nephrotic syndrome related to autoimmune hypothyroidism," JRSM Short Reports, vol. 2, no. 8, pp. 1-3, 2011.

[7] D. Lang, J. S. Mead, and D. B. Sykes, "Hormones and the bone marrow: panhypopituitarism and pancytopenia in a man with a pituitary adenoma," Journal of General Internal Medicine, vol. 30, no. 5, pp. 692-696, 2015.

[8] S. H. Song, C. J. McCallum, and I. W. Campbell, "Hypoplastic anaemia complicating myxoedema coma," Scottish Medical Journal, vol. 43, no. 5, pp. 149-150, 1998.
[9] L. H. Salomo, A. H. Laursen, N. Reiter, and U. Feldt-Rasmussen, "Myxoedema coma: an almost forgotten, yet still existing cause of multiorgan failure," Case Reports, vol. 2014, Article ID bcr2013203223, 2014.

[10] H. Shaaban, T. Modi, Y. Modi, and I. Sidhom, "Hematologic recovery of pancytopenia after treatment of Hashimoto's thyroiditis and primary adrenal insufficiency," North American Journal of Medical Sciences, vol. 5, no. 3, pp. 253-254, 2013.

[11] B. McMahon and S. Kamath, "Pancytopenia in a patient with hypothyroidism," JAMA, vol. 315, no. 15, pp. 1648-1649, 2016.

[12] D. J. Anjaria, P. Rameshwar, E. A. Deitch et al., "Hematopoietic failure after hemorrhagic shock is mediated partially through mesenteric lymph," Critical Care Medicine, vol. 29, no. 9, pp. 1780-1785, 2001.

[13] B. Fontes, F. A. Moore, E. E. Moore et al., "Gut ischemia induces bone marrow failure and increases risk of infection," Journal of Surgical Research, vol. 57, no. 4, pp. 505-509, 1994.

[14] H. Soleimanpour, S. Safari, F. Rahmani, A. Nejabatian, and S. M. Alavian, "Hepatic shock differential diagnosis and risk factors: a review article," Hepatitis Monthly, vol. 15, no. 10, article e27063, 2015.

[15] J. J. Gomez-Ramos, A. Marin-Medina, S. E. Prieto-Miranda, I. P. Dávalos-Rodríguez, M. A. Alatorre-Jiménez, and E. Esteban-Zubero, "Determination of plasma lactate in the emergency department for the early detection of tissue hypoperfusion in septic patients," American Journal of Emergency Medicine, vol. 36, no. 8, 2017.

[16] Epocrates, 2019, https://www.epocrates.com.

[17] MedScape, 2019, https://www.medscape.com/internalmedicine.

[18] Uptodate, Drug Information Search, 2019, https://www. uptodate.com.

[19] FDA, 2019, https://www.fda.gov/about-fda.

[20] E. C. Logan, L. M. Williamson, and D. R. Ryrie, "Sulphasalazine associated pancytopenia may be caused by acute folate deficiency," Gut, vol. 27, no. 7, pp. 868-872, 1986.

[21] R. Sarode, G. Garewal, N. Marwaha et al., "Pancytopenia in nutritional megaloblastic anaemia. A study from north-west India," Tropical and Geographical Medicine, vol. 41, no. 4, pp. 331-336, 1989.

[22] F. Yousaf, B. Spinowitz, C. Charytan, and M. Galler, "Pernicious anemia associated cobalamin deficiency and thrombotic microangiopathy: case report and review of the literature," Case Reports in Medicine, vol. 2017, Article ID 9410727, 8 pages, 2017.

[23] C. Rhodes and M. Coma, "Diagnosis and treatment," American Family Physician, vol. 62, no. 11, pp. 2485-2490, 2000. 


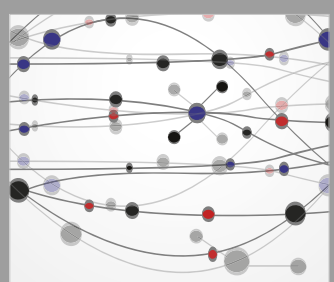

The Scientific World Journal
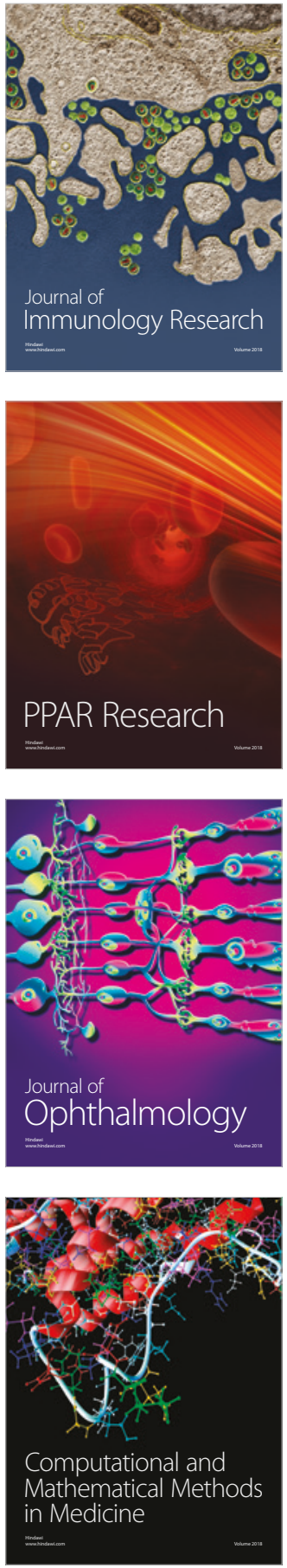

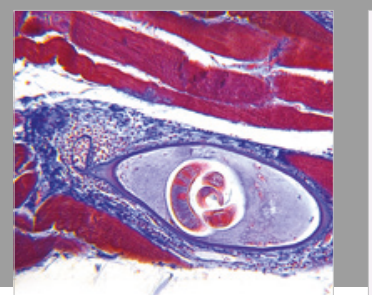

Gastroenterology Research and Practice

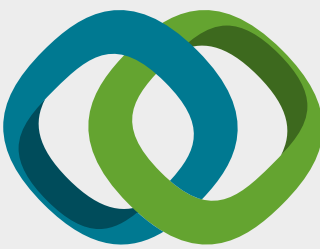

\section{Hindawi}

Submit your manuscripts at

www.hindawi.com
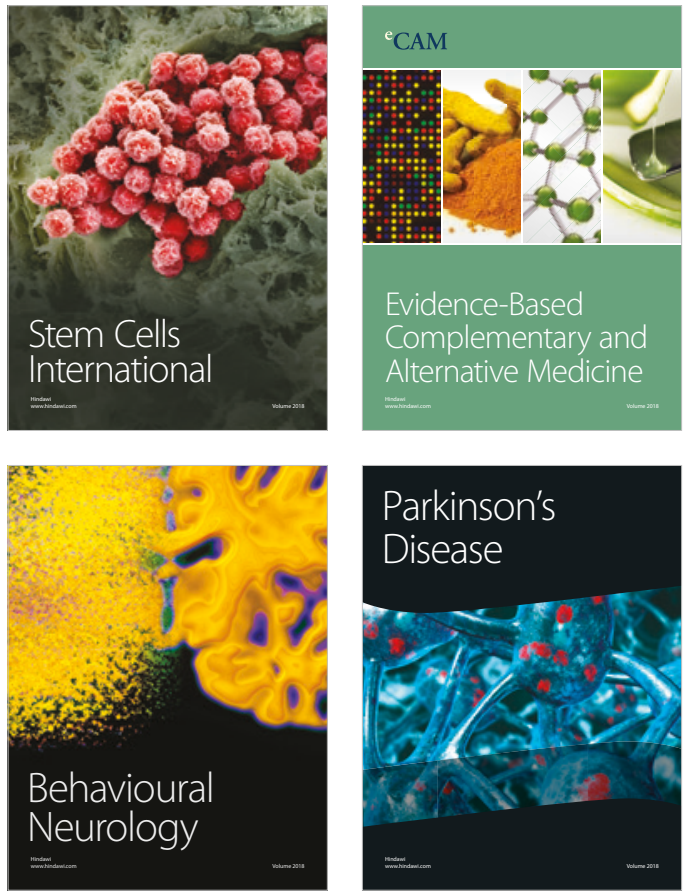

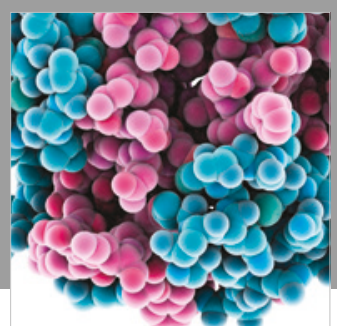

ournal of

Diabetes Research

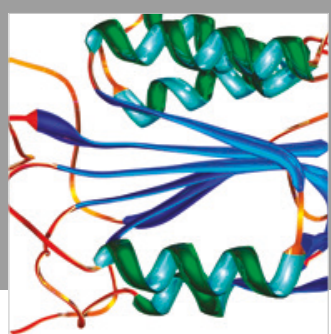

Disease Markers
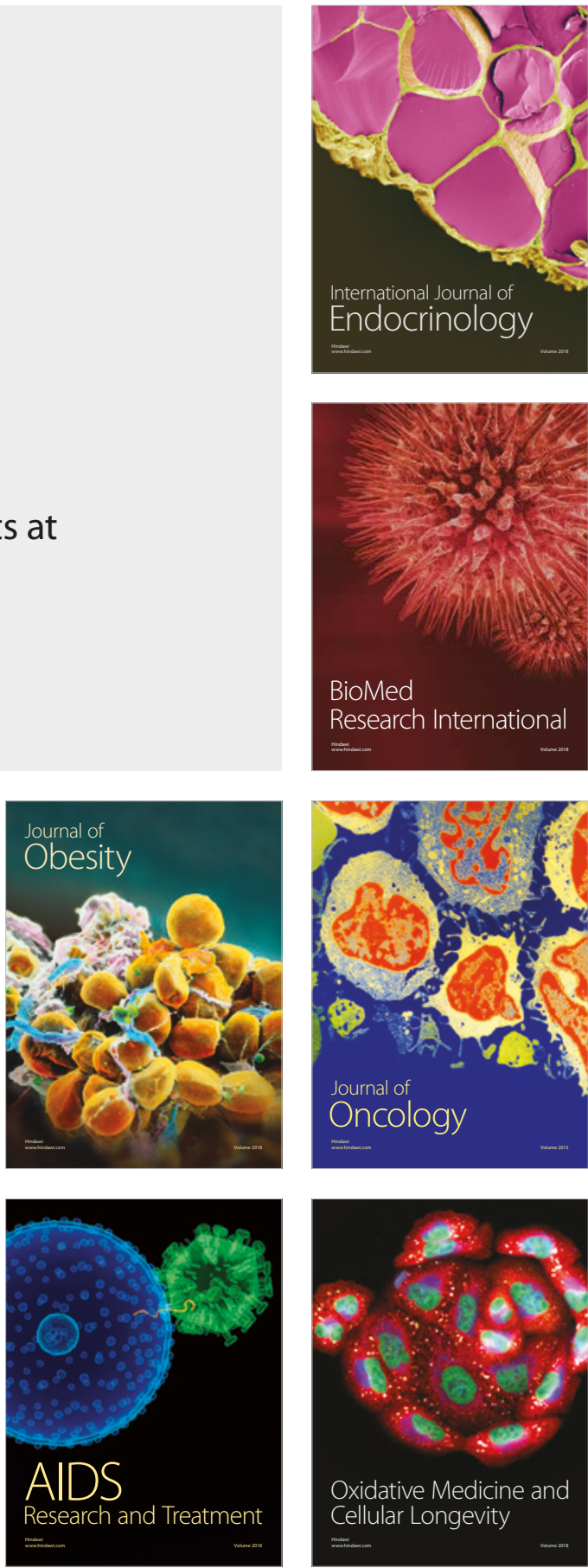